\title{
Empire and Scottish Society
}

The Impact of Foreign Missions at Home, c. 1790 to c. 1914

Esther Breitenbach

Edinburgh University Press 
Esther Breitenbach, 2009

Edinburgh University Press Ltd 22 George Square, Edinburgh www.euppublishing.com

Typeset in Linotype Sabon by Iolaire Typesetting, Newtonmore, and printed and bound in Great Britain by CPI Antony Rowe, Chippenham and Eastbourne

A CIP record for this book is available from the British Library

ISBN 9780748636204 (hardback)

The right of Esther Breitenbach to be identified as author of this work has been asserted in accordance with the Copyright, Designs and Patents Act 1988. 